\title{
The Future of NATO
}

\author{
Adam Daniel Rotfeld
}

Abstract: Different from other institutions founded prior to the end of the Cold War, NATO's existence is not challenged. The transatlantic alliance has undergone transformations and faces global tasks. But NATO lacks a concept to arrange and regulate the structure of the Alliance under new circumstances. In particular, answers are needed to the questions of further enlargement, NATO's relation with Russia and the nature of the links between NATO and the European Union. A new approach is required to cope with the dramatic change in the global situation and lay down new tasks for the Alliance.

Keywords: NATO, Enlargement, European Union, Russia

\section{Introduction}

A ccelerated change on the international arena has made the issue of transformation and the future of multilateral security institutions the focal point of international debate. Some of the institutions, following their attempts to adapt to the new circumstances, have virtually died out, with their functions taken over by other organisations. This applies, for example, to the Western European Union. Other institutions, such as the OSCE, are facing a formidable dilemma: how to adjust their mandate to the new situation. A question increasingly often asked is whether these organisations have a future?

The North Atlantic Alliance is not facing these dilemmas. It is important to note in this context that, essentially, institutions and alliances do not live forever. They are formed, developed and become affected by changes, to finally become obsolete. International organisations and structures, political and military alliances are established at a specific moment in history in order to meet specific needs of international coexistence. This stage is usually referred to as the origin of a security institution. The next stage is the development of the institution, performing specific tasks under the circumstances that formed it. Usually, after the mission is accomplished and new historical circumstances come into play, all institutions are confronted with the question: what now?

One of the crucial criteria to verify the longevity of each international organisation, and military alliances in particular, is whether the organisation is attractive for the states that remain outside of its structures. In other words, what is important for NATO is to answer the question of whether the Alliance is still attractive for other states and whether it is a centre of gravity. This provokes further crucial questions:

- Is NATO's transformation, triggered immediately after the end of the »Cold War«, a continuous process, and to what extent is NATO an adequate tool to answer the new threats of today?

- Is there a conflict between enlargement and the Alliance's new tasks outside its boundaries on the one hand, and

* An earlier version of this article was published in "Sprawy Miedzynarodowe No.3/2006. Prof. Dr. Daniel Adam Rotfeld, former Minister of Foreign Affairs of Poland, former direkctor of the Stockholm International Peace Research Institute, Sweden. deepening the institution's internal transformation on the other?

- Are there limits, and if so, what are they, to the military alliance's commitment outside its authorised area of operation? How far can NATO go in its actions going beyond what has been agreed upon in its statute?

- Are the multilateral NATO associate organisations (such as PfP - Partnership for Peace and EAPC - Euro-Atlantic Partnership Council) fulfilling their tasks and addressing the needs of both the Alliance's members and its partners, or do they require sweeping changes?

- What is the essence of the new quality in Russia-NATO relations, and to what extent is a greater intensity of these relations a factor that may impact the process of Ukraine getting closer to NATO, which has recently started?

- What are the key problems with US-Europe relations? Is the Alliance, as seen by the United Stated, losing or gaining importance?

- What are the Alliance's driving forces? Are the two superpowers (France and Germany) the key players in ensuring military security, or, following the formation of a wide coalition in Germany, is Berlin perhaps returning as an important actor in the process of ensuring military security on the global scene?

- Finally, what should be done for NATO and the European Union to work out a common, Euro-Atlantic policy? How can a transition from verbal declarations on the issue to a structured and institutional cooperation be achieved?

These questions are neither rhetoric nor new. It is worthwhile to reiterate them and attempt to find the answers that would take into account the new political and military situation in Europe and worldwide. These questions are asked by both superpowers that are members in the Alliance and states that aspire to membership.

This text first looks at crucial factors which frame NATO's future, cast in terms of relations with the United States, Russia, and the Soviet Union. It then reviews a number of proposals on transformation of NATO before drawing some conclusions. 


\section{NATO and transatlantic relations}

Two factors are of paramount importance for the future of the North Atlantic Alliance:

1. the position of the United States and the role that the present Washington administration wants for NATO within its national security policy, and

2. transatlantic bonds, that is political and military links between the US and Europe, notably in NATO-EU-US configuration.

By March 2007, fifty years will have passed from the signing of the Rome Treaty that gave birth to the European Union. Two years later, in April 2009, we will celebrate the $60^{\text {th }}$ anniversary of the formation of the North Atlantic Alliance. As viewed by serious American and European analysts, both transatlantic structures are at the crossroads: their partnership »may become closer and stronger, or they will be more divided and accordingly weaker ${ }^{1}$.

The key issue here is how to reconcile the partnership between Europe and the United States with the American leadership in the Alliance. In recent years, representatives of the American administration were not willing to open a big, public debate on the strategy and future of the Alliance. Their assumption was that the effects that debate of this type may bring will be contrary to those expected, namely that they may question the American leadership, lead to imposing the strategic objectives of their European allies, important from the viewpoint of a united Europe, on the United States and, overall, result in the foundation of transatlantic relations being challenged. Americans opted for a concept which may be called the »ship's reconstruction at sea «. From their point of view the fact that »the ship has not sunk « legitimises their approach. The Alliance is still existent. What is more, NATO is expanding its mandate, practically reaching boundaries inconceivable in the past (stabilisation in the Balkans and Afghanistan, training the armed forces of Iraq, counteracting a humanitarian crisis in Darfur). This approach may be abbreviated as transforming by doing. The process itself cannot be deemed to be a proper transformation of the Alliance. The military intervention of the United States in Iraq was accompanied by their attempts to redefine the Alliance as the toolbox and the »coalition of the willing «. It is worth remembering that the decision on the Alliance's transformation was taken in London (5-6 July, 1990). The last sentence of the Declaration adopted at that time started with »Today, our Alliance begins a major transformation $(. ..) \ll^{2}$. This transformation has been continuing until today, although we have not seen an attempt at a new major strategy since 11 September, 2001.

A notable change following the »Cold War « was that the Alliance, by definition encompassing the transatlantic area, as specified in the Washington Treaty from 1949, became glo-

1 S. Serfaty, A Challenged and Challenging Europe: Impact on NATO-EU-US Relations, »The International Spectator « 2006, No. 1, p. 61. See also A. Monaghan, Russia, NATO and the EU: A European Security Triangle or Shades of a New Entente? Ed. Russia. Nei. Visions No. 10 a, IFRI, Paris, May 2006.

2 As quoted by the documentation appended with the work by A.D. Rotfeld and W. Stützle (eds.), Germany and Europe in Transition, SIPRI-Oxford University Press 1991, p. 152. bal. Its objectives are set on an ad hoc basis and depend on the needs and available potential. This brings us closer to the first fundamental issue: Should NATO be careful not to bite off more than it can chew, or rather set objectives that are a stimulus for its capabilities? When defining NATO's place among other centres of global power, the recently adopted National Security Strategy of the United States of America ranks the Alliance among humble regional actors, rather than global players. The authors of the document placed Europe fourth behind the Western hemisphere, Africa and the Middle East ${ }^{3}$. The authors of the Strategy claim that: »NATO remains a vital pillar of U.S. foreign policy. The Alliance has been strengthened by expanding its membership and now acts beyond its borders as an instrument for peace and stability in many parts of the world $\ll^{4}$. The internal reform of NATO, the American documents argue, in terms of its structures, capabilities, and procedures "must be accelerated to ensure that NATO is able to carry out its missions effectively«. In other words, the objectives have been set and the capabilities should be adjusted accordingly. For the first time, the European Union finds its role in the American strategy: "NATO must deepen working relationships between and across institutions, as it is doing with the EU, and as it also could do with new institutions $\ll^{5}$.

\section{Deepening or enlargement?}

The antinomy between the Alliance's enlargement and deepening the transformation process was the theme of a host of analyses $^{6}$. The opponents of the Alliance's enlargement argue that the accession of new members will practically petrify the old structures, mechanisms and procedures. The enlargement's proponents take a different view. They believe that the inclusion of young democracies from Central Europe will accelerate internal reforms. This dispute is already a thing of the past. The enlargement was conducive to NATO's revitalisation but did not contribute to its deepened transformation.

The limit of the enlargement is the question of the day. Should the process of further enlargement be slowed down after the accession, on 29 March 2004, of seven new states (Bulgaria, Estonia, Latvia, Lithuania, Romania, Slovakia and Slovenia)? If the answer is yes, what are the limits to adhere to? This was the fifth enlargement of the Alliance since its inception, and the second post-cold war accession. An important marker for the concept of the Alliance's enlargement was the Study on NATO enlargement of $1995^{7}$. The document provided answers to the question of why the enlargement is recommended, and

\footnotetext{
3 The National Security Strategy of the United States of America, Washington, March 2006, chapter VIII: Develop Agendas for Cooperative Action with the other Main Centers of Global Power, p. 35-42.

4 Ibidem, p. 38.

5 Ibidem.

6 Several publications from recent years may serve as examples here, including. R. Asmus, Opening NATO's Door. How the Alliance Remade Itself for a New Era, Columbia University Press 2002 (NATO - otwarcie drzwi, Warszawa 2002, p. 246-507); essay by the head of NATO Planning Section, Michael Rühle, A more political NATO, "NATO Review« Special Issues, Winter 2005, pp. 4-6; P. van Ham, Growing pains, ibidem, pp. 7-9. Two statements were presented by Lionel Ponsard (of NATO Defence College in Rome) and David S. Yost (Naval Postgraduate School in Monterey), to answer the question »Is it time to update NATO Strategic Concept? «, ibidem, pp. 10-11.

7 Study on NATO Enlargement. NATO, Brussels 1995.
} 
how to proceed with it. In essence, the answers given in the study are still valid. The Alliance should continue with the philosophy of open doors and ensure the newcomers' compliance with the terms of accession. Optimistic expectations have come true and the argument of the study was that the enlargement would contribute to:

- firstly, stabilisation in the region, as the candidate countries made efforts to bury the hatchet of historical feuds and conflicts (in the past, membership in the Alliance prevented the conflict between Greece and Turkey);

- secondly, the adoption of political and military standards applicable within the Alliance (including civil control over the armed forces);

- thirdly and finally, it is a process of expanding the mandate and transformation. This convinced the new states to join the fulfilment of the Alliance's new tasks outside its borders $^{8}$.

Today, NATO is facing the necessity to define its attitude towards the aspiring members - the Balkan states, Georgia, and, most of all, the Ukraine. The Ukraine's accession to NATO is a problem of political, rather than military nature. We should not forget that the armed forces reform in the Ukraine was much smoother than the reforms in other areas of political and economic reality. This proves a serious, and qualitatively new, problem and a political challenge, notably due to Russia's attitude towards the NATO.

\section{NATO and Russia}

Russia takes a double-sided stance towards the NATO. On the one hand, the state has been for years publicly showing its criticism towards the Alliance. On the other, it demonstrates a pragmatic attitude on the forum of the Alliance and in political practice, little known to the public. Moreover, it highly values its status of cooperation with the Alliance.

This is not a new phenomenon. It is worth reminding that, already in September 1993, president Boris Jelcyn, following his official visit to Warsaw, addressed a letter to the heads of the Western superpowers, explaining that »We do not perceive NATO as a bloc that opposes us. However, it is important to remember that our public opinion may respond to this step [accession of Central European states to the NATO. The opposition and the level-headed alike will treat it as a peculiar neoisolation of the country, at variance with the natural process of our inclusion in the Euro-Atlantic area « ${ }^{9}$. And: »Generally, we prefer a situation where the relations between our country and NATO are by several degrees warmer than those between the Alliance and Eastern Europe. The coming together of NATO and Russia, combined with cooperation in peace building, should become a reality soon ${ }^{10}$.

8 Cf. more on the subject: R. Asmus, op. cit.; J. Simon, Poland and NATO. A Study in Civil-Military Relations, Maryland 2004.

9 Full text of the letter was published as annex in: A.D. Rotfeld, Europe: towards a new regional security regime, »SIPRI Yearbook 1994«, pp. 249-250.

10 Ibidem.
It has been thirteen years since this letter was written. In the meantime, NATO welcomed Poland, the Czech Republic and Hungary (12 March, 1999). Their accession to the Alliance was preceded by a unilateral declaration by the NATO's general secretary (14 March, 1997): »In the current and foreseeable security environment, the Alliance will carry out its collective defence and other missions by ensuring the necessary interoperability, integration and capability for reinforcement [of the armed forces] rather than by additional permanent stationing of substantial combat forces ${ }^{11}$.

Combined with the NATO declaration (10 December, 1996) that the Alliance has "no intention, no plan, and no reason « to deploy nuclear weapons on the territory of new members, this assurance was a sign that it was taking into consideration the security interest of Russia and its fears over the Alliance's enlargement ${ }^{12}$.

In turn, before the accession of the seven new states, the NATO summit at the military base in Pratica di Mare near Rome (May 2002), convened for that purpose, adopting a declaration on »qualitatively new relations « between NATO and Russia. The Russia-NATO Council was also formed ${ }^{13}$.

It is worth noting that Russia, as a rule, evaluates the Council's work in a very positive way and, when it does express its criticism, it is chiefly for NATO's failure to use the Council's potential to the full. In other words, as argued by Russia, the Council »addresses the long-term interest of Russia and members of the Alliance «. Russian proposals relate to the deepening of cooperation with the Alliance and »improving the normative and legal basis, " so that the mutual arrangements are not only of a political nature, but are also applicable as the provisions of international law.

On 8 December, 2005, Russia presented a long list of points to discuss within the NATO-Russia Council. Interestingly, the list covers directions and ways for further transformation of the Alliance. On the one hand, in line with the Russian proposals, the Alliance should provide relations with Russia on a legally binding basis. On the other, Russia opposes further enlargement of NATO, as it could have adverse effects on its security and would lead to destabilisation, reduced mutual confidence, and entail an increase of Russia's military spending. In other words, Russia is striving to achieve a relationship with the NATO that would provide it with insights into key political and military issues and the right to put the enlargement process on hold. Russia is not a NATO candidate, as it would involve certain obligations. However, it would be happy to steer the events in the direction where the Alliance's hands are tied and its decisions are dependent on Russia's say. The document of December 2005, with detailed operational proposals, was presented as a comprehensive concept by minister Sergey Ivanov at the Munich Security Conference

11 »NATO Press Release« (97), Brussels, 14 March 1997. Cf. more on the subject: A.D. Rotfeld, Europe: the institutionalized security process, SIPRI Yearbook 1999, p. 247.

12 Cf. A.D. Rotfeld, NATO a new role and mission, ibidem, pp. 238-250.

13 NATO-Russia Relations: A New Quality. Declaration by Heads of State and Government of NATO Member States and the Russian Federation, http://www.nato.int/docu/basictxt/b020528e.pdf 
(4/5 February 2006) ${ }^{14}$. Ivanov also noted a number of issues, where the interests of Russia and the Alliance converge. This applies in particular to non-proliferation of mass destructive weapons and the fight against terrorism. However, as regards both issues, Russia is striving for the weapons exports control not to obstruct its arms trade, as the transfer of weapons becomes one of Russia' new specialties. There are grounds for a closer cooperation between NATO member states and Russia on fighting terrorism. However, a common concept for the fight against international terrorism is too often used to justify a large scale use of armed forces all over the North Caucasus, notably in Chechnya. Overall, Russia wants the North Atlantic Alliance to adopt its perspective in assessing the situation and then, and only then, may its cooperation with NATO develop unobstructed.

The development of political and military relations between Russia and the Alliance has three aspects: bilateral relations with NATO members, cooperation with the Alliance's institutions in a multilateral mode, and, together with the European Union, in a trilateral format ${ }^{15}$. The new Russian political and military doctrine reveals an important return to the old Soviet perception of threats. The highest-ranking threat, identified by the doctrine, is »interference in Russia's internal affairs by foreign states - either directly or indirectly through structures they support ${ }^{16}$. There is no doubt that this veiled form conceals a negative evaluation of Euro-Atlantic structures (NATO and EU), the OSCE and the Council of Europe. Further down Ivanov's list are other threats: terrorism and proliferation of weapons of mass destruction.

In minister Ivanov's opinion, there is no conflict between NATO and Russia as to the perception of transnational threats and operational military cooperation in the fight against terrorism. His statement, delivered in Munich in February 2006, boiled down to the conclusion that the NATO-Russia Council mechanism should be provided with a practical military aspect based on transparency, reciprocality, and prevention of double standards.

All in all, the Alliance will remain a major partner for Russia, provided that the latter is granted the right to co-define NATO's developmental directions and strategies.

\section{NATO and the European Union}

The idea of establishing new conceptual framework for cooperation between the Alliance and the European Union deserves a serious brainstorm. It is common belief that the Alliance has moved from a regional to a global organisation. The task of defending common territorial integrity of the member states is treated today on par with ensuring security and stabilisation outside the statutory area. The new approach by NATO and the European Union should take the direction of looking for

14 In his speech in Munich (Russia, Europe, and the World-Prospects for Cooperation on Global Security Issues, 5 February, 2006) Sergey Ivanov said: "Nowadays Russia and NATO have the same approach to estimation of transnational threats in the field of security

15 S. Ivanow, The New Russian Doctrine, »The Wall Street Journal « of 11 January, 2006.

16 Ibidem. solutions that expand the mandate in the political, military, and geographical sense, while at the same time prevent the weakening of the traditional classic defence function of the Alliance. This translates into the requirement to strengthen integrated defence of NATO states, with all the implications this task carries. This function can be solidified if the Alliance's new tasks focus on preventing new threats, not only in the military, but also in the economic dimension. This applies in particular to ensuring energy safety and »neutralisation « of terrorist threats, no matter what its origins are.

In a world of interdependencies, in the context of globalisation and integration processes, notably within the transatlantic community, the missions that the Alliance is tasked with can be successfully pursued in a close and institutionalised relation with the European Union. This refers both to tasks defined by the Alliance's Strategic Concept (24 April, 1999) as well as those proposed four years later by the European Security Strategy of 12 December, 2003, adopted at the summit of the European Union ${ }^{17}$. The tasks comprise: fighting global terrorism; peacekeeping, security and reconstruction operations, that is the reconstruction of both the damaged infrastructure assets, and of the states' governance capabilities (Bosnia and Kosovo in Europe and Afghanistan in Asia serve as examples here); ensuring security of »critical infrastructure « - chiefly energy industry, power lines, etc. and finally, preventing the proliferation of weapons of mass destruction. The list of common tasks of the Alliance and the Union has more items to offer. The real problem is not the artificial concept of the division of duties but common actions of both transatlantic structures:

- If NATO and the EU want to promote democratic transformations worldwide, there must be a way to pursue this mission together and in an efficient manner.

- If our security is threatened both internally and externally (from territories far away from Europe), our counteraction must correspond to the new nature of these threats.

- If the dividing line between security and threat, both external and internal, gets blurred, neither the Alliance nor the Union may ignore the needs that in the past belonged to discretionary powers of each sovereign state.

- If terrorism, nowadays in most cases inspired by aggressive Muslim fundamentalism, is considered to be the main threat, the language of political correctness may not thwart a common response by the Alliance and the European Union. Theoretical and scientifically modelled reflections upon a potential change of the Washington Treaty are not the point here. This change is neither necessary nor needed. We may, or should, look for other pragmatic solutions, paying attention to the need for common understanding of the new challenges and threats.

17 "The Alliance's Strategic Concept «, 24 Apr. 1999 , Press Release NAC-S (99)65. The Union's strategies, in the version proposed by Javier Solana, were approved by the European Council, with heads of states and governments, held in Brussels on 12 December, 2003. Text: A secure Europe in a better world. European Security Strategy, Paris 2003 


\section{Proposals and suggestions for transformation}

It would be naïve to think that a new report, even if drafted by world's best experts, would yield ready-made solutions. However, shared opinions addressed to the Alliance and the Union may prove an inspiration for politicians. Many reports have been published tackling the issue of the Alliance's future. Three documents deserve special attention.

First of these is Renewing The Atlantic Partnership (2004), prepared by the Council of Foreign Relations ${ }^{18}$. The recurring theme of the report was counteracting anti-Americanism, increasingly popular in Europe, and an urgent need for restoration of the spirit of partnership in relations between the leaders of the United States and Europe. The principles that guide NATO today, argue the report's authors, remain valid, but are not necessarily put into practice. Nowadays, there is no need for a further substantial military presence in the centre of Europe. The threats facing the Alliance today are more varied than at the time of the »cold war «. That is why American and European security interests will not correspond to each other in the future, as they did in the past The authors of the report suggest that the Alliance should be more flexible in its procedures and more ambitious in its missions than it was in the past.

The second report, Transatlantic Security: New Realities, Changing Institutions, came from the Warsaw Reflection Group, with renowned pundits on the subject - researchers, experts, and former politicians from the United States and Europe ${ }^{19}$. The authors of the report provide, in the conclusions section, four theoretical scenarios for EU-NATO relations:

- Inclusion of EU into NATO. This daring step, no matter how abstract its conceptual basis, would not be, as argued by the authors, as dramatic as other decisions taken in the last decade. It remains doubtful, however, whether the EU member states that are not NATO members would agree to this solution.

- Representation of EU at NATO meetings. The Alliance could agree to a temporary participation of the Union's representatives - upon compliance with certain civilian and military conditions. This would be another category of "special relations «. If this solution is feasible with Russia and the Ukraine, there are no reasons to justify the relationship with the Union being, in principle, less privileged.

- Another proposal is the institutionalisation of the relations between EU and the United States (and NATO?). WRG participants shared the conviction that this transatlantic institutionalisation of relations between the two structures is desirable. A step in that direction would be an appointment of the joint NATO-Union Secretariat, or a trilateral EU-NATO-US Secretariat. It would prevent the formation of alternative solutions in transatlantic relations.

18 Report of an Independent Task Force, Renewing the Atlantic Partnership, New York 2004. Co-chairmen of the team appointed by the Council on Foreign Relations were Henry Kissinger and Lawrence H. Summers, while the project director was Charles A. Kupchan.

19 Transatlantic Security, New Realities, Changing Institutions. Report of the Warsaw Reflection Group - Chairman Adam Daniel Rotfeld, Rapporteur - Steven E. Miller, Warsaw, April 5-6, 2004.
- The fourth, and the most ambitious suggestion, is the establishment of a new mechanism for coordinating crisis-prevention policies. The developments in the Middle East and Persian Gulf fully justify this proposal. The fact that this mechanism does not exist today is detrimental both to NATO and the Union.

The third report, NATO: An Alliance for Freedom, was presented by Spain's Prime Minister, Jose Maria Aznar, at the American Enterprise Institute on 16 November $2005^{20}$. In his speech, Mr. Aznar offered three arguments: firstly, irrespective of the Alliance‘s hyperactivity, »it is in a very deep crisis«; secondly, NATO lost its compass following the collapse of the Soviet Union, and is drifting towards an organisation that exports stabilisation worldwide; thirdly, traditional concepts of the Alliance, such as the policies of containment and deterrence, do not tally with the present needs and threats. NATO's crisis does not result from poor or insufficient military capabilities, but rather from material differences in perceiving the idea of threat. Aznar proposes the restoration of the Alliance's central role in shaping the transatlantic community policy as an instrument for »collective defence $«$, able to face new threats, notably the Muslim terrorism.

It transpires that the arguments of these three reports are convergent in many areas, although their authors neither contacted the other teams, nor »borrowed « their reflections. The reports also share some weaknesses. They result from a simple fact, namely that the authors are trying to convince themselves that the function of the Alliance so far, that is ensuring security for its members, performs almost impeccably under the present circumstances. And the changes, if needed at all, do not pertain to the nature of the organisation's operation.

\section{Conclusion}

To sum up the discussion in this article, and to point at answers to the questions asked in the introduction:

1. The transformation of the Alliance may not be perceived as a single event, or an implementation of a decision taken at NATO summit. Transformation is a process of continuous and permanent adjustment of the Alliance to address new circumstances, new threats, new needs, and tasks.

2. The enlargement of the Alliance beyond the traditional borders and deepening of its internal transformation are essentially parts of the same process, with streamlining of NATO efficiency under the new circumstances at its core. The enlargement and transformation are continuous processes, as the entire international security system is subject to a continuous change.

3. The transatlantic alliance has undergone transformations and faces global tasks. This results from the fact that the threats of today are essentially of global nature. The attempts to keep the Alliance's activities within the confines of the statutory mandate would marginalise NATO's importance. Since the threats appear outside the statutory area, effective counteracting must also reach out of the area.

20 J.M. Aznar, NATO: An Alliance for Freedom, Presentation at the AEI, November 16 th, 2005 
4. Multilateral institutions associated with NATO - such as the Partnership for Peace (PfP) or the Euro-Atlantic Partnership Council (EAPC) - have played an important stabilising role. They have been a practical application of the philosophy of inclusiveness, rather than exclusiveness, to states that could not (or did not want to) become members of the North Atlantic Treaty. Today, these institutions should be governed by the same transformation that applies to other NATO structures.

5. The relations between Russia and NATO must address the security interest of both partners. The document on »qualitatively new NATO-Russia relations «, adopted in spring 2002 , is still fully valid. The opportunities and prospects for establishing partner relations have not been exhausted yet, as a giant leap forward has been made in recent years in terms of practical cooperation. Special relations between the Alliance and Russia should not be an obstacle in getting the Ukraine closer to the NATO, with full membership of the country in the Alliance in the long-term perspective. This development would reflect both the long-term security interests of the Ukraine and Russia, and the transatlantic community, and would contribute to greater stabilisation in the region.

6. Relations between Europe and the United States are of seminal importance for the Alliance's future. The analyses and conclusions presented in the three reports suggest the establishment of new types of links between NATO and the European Union. The time has come for politicians and leaders responsible for the security of the transatlantic community to pay proper attention to this proposal from independent and distinguished authorities.

7. To reconcile the strategies of national defence of individual states and superpowers with the security interests of the entire community and the Western civilisation as a whole, is key to the security of the member states of both organisations (NATO and EU). Here, far-reaching and beneficial changes have also been made, notably in relations between the US and Germany. The latter state, following the American intervention in Iraq, not only distanced itself from this policy, but also questioned the key role of NATO as the platform for shaping a common transatlantic strategy.

8. Today, NATO and the European Union (to some extent, the entire Europe and the United States) are facing formidable challenges, even more dramatic than those that the leaders of the transatlantic community in the mid-sixties of the previous century were confronted with. The decision taken at that time was for the Alliance to revise, in a creative and innovative manner, its strategy towards the East. Harmel's report of the time expressed a new political philosophy: ideological confrontation was accompanied by a proposal for a new opening - „Change Through Rapprochement « (Wandel durch Annäherung) ${ }^{21}$, which resulted in a gradual normalisation of Germany's relations with their neighbours from the East and, over time, opened up avenues for the process that commenced at the Conference on Security and Cooperation in Europe (1973-1975).

The problem with NATO is not insufficient power, but rather the lack of a concept that would arrange and regulate the structure of the Alliance under new circumstances. This absence may lead to the erosion and extinction of some institutions that played an important role in the past. As the permanent crisis and military confrontation appears to be the main threat for the transatlantic community and the world, the Alliance will have to, sooner or later, define its missions in this respect ${ }^{22}$.

Harmel's report was a conceptual breakthrough for the new strategy of the Alliance towards the Eastern Bloc $^{23}$. Under completely different political and military circumstances, the task of the Alliance is substantially more difficult, as it addresses not only Europe, but also global threats, whose nature has not been completely grasped. This applies not only to a handful of states that challenge the entire international community (Iran, North Korea), but also to many non-state structures and entities (Hezbollah and Hamas), that states (e.g. the Lebanon and the Palestinian Autonomy) cannot cope with, often left defenceless and helpless.

Today, we need a new approach that would answer a dramatic change in the global situation and lay down new tasks for the Alliance. Such tasks should efficiently promote worldwide change, modernisation and the respect of laws. The Alliance cannot be left to drift away. Axiology also, in formulating the Alliance's strategy, is of importance here.

21 The author of this concept was Egon Bahr, at that time responsible for the political strategy of the German social democratic party.

22 T.F. Lynch III, NATO Unbound: Out-of-Area Operations in the Greater Middle East, »Orbis. A Journal of World Affairs«, vol. 49, No. 1, Winter 2005, p. 141

23 The Future Tasks of the Alliance: NATO's Harmel Report, 1966/67, in: A. Locher/Ch. Nuenlist (eds.), »Parallel History Project on NATO and the Warsaw Pact.«, Center for Security Studies Washington/Zurich, July 2004, http://www.isn.ethz.ch/pubs/ph/details.cfm?lng=en\&id=13623. 